\title{
Legal Liability: The Board of Directors
}

\author{
Cindy A. Schipani, George J. Siedel
}

As director liability problems increase, it becomes increasingly important for directors to understand their legal responsibilities.

Ninety percent of the chief executive officers in American corporations believe that the liability problems of directors and officers are damaging the quality of corporate governance, according to a survey released in 1987 by Peat Marwick. The survey of almost eight thousand chief executives in both the corporate and nonprofit sectors is believed to be the most comprehensive liability survey ever conducted. Approximately one third of the executives overall and one half of those from smaller corporations concluded that the liability problem had already reached a crisis stage, and one fourth of the executives reported that their directors had been involved in litigation relating to director liability (" $\mathrm{D} \& \mathrm{O}$ Liability," 1987).

The concern over liability illustrated by this survey has led the owners of family businesses to question the role of the board of directors. What is the general legal function of the board? How might this function be different in a family-owned corporation? How does the board's legal function translate into liability? How can directors prevent liability or at least protect themselves from the consequences of liability? This article addresses these questions.

In most states, general corporation law is based on a model act developed by the American Bar Association. The latest version of this act is the Revised Model Business Corporation Act of 1984 (Revised Model. . . , 1985). While the general principles of corporation law apply to all types of corporations, several states have adopted specific provisions for family and other close corporations. The Model Statutory Close Corporation

Note: The authors wish to thank Philip M. Dawson, a partner in the law firm of Calfee, Halter \& Griswold, Cleveland; Brian Sullivan, a partner in the law firm of Dykema, Gossett, Spencer, Goodnow \& Trigg, Detroit; and Joel D. Tauber, president of Key International Manufacturing, Inc., Southfield, Michigan, for their helpful comments. 
Supplement (Revised Model . . , 1985) adopted by the American Bar Association assembles these provisions. In this article we will discuss both general principles of corporation law, which we will refer to as the Model $A c t$, and specific family business provisions, which we will refer to as the Close Corporation Supplement.

\section{The Board's Legal Function}

In the classic corporate model, the directors have ultimate management responsibility. According to Section 8.01 of the Model Act, "all corporate powers shall be exercised by or under the authority of, and the business and affairs of the corporation managed under the direction of, its board of directors." In practice, boards can delegate powers to board committees, subject to exceptions, such as amending articles of incorporation and bylaws. The board can also delegate to officers the authority to implement board policies.

The classic model frequently breaks down in the family corporation setting for two reasons. First, even when the corporation has adopted the classic legal structure, the structure is often ignored in practice because the founder of the firm, sometimes aided by other family members, makes all decisions. Under these circumstances, boards are little more than paper or rubber-stamp boards (Dyer, 1986).

Second, the family corporation may choose to adopt a nontraditional legal structure. The Close Corporation Supplement provides that a family corporation can operate without a board of directors, in which case the responsibilities and liabilities that normally fall on directors are placed instead on the voting shareholders.

Furthermore, even if the corporation has a board of directors, the shareholders can agree to transfer management responsibilities from the directors to the shareholders. The effect of such an agreement is that the business can be operated as if it were a partnership.

When a family corporation decides to sterilize the board of directors through a shareholder agreement or to eliminate the board completely, the creation of an advisory board is often recommended. This board counsels owners on matters handled by a traditional board of directors, such as corporate policy, long-range planning, capital expenditures, and employee compensation. But, perhaps more important, the advisory board plays a critical role in succession planning. Danco does not overstate the case when he notes $(1982$, p. 137) that "the single most important job of the board of directors in the family corporation should be . . to provide for the profitable continuity of the firm. It must promote proper management development to allow for the 'passing of the torch' from the founder generation to the successor generation."

While no legal requirements govern selection of the advisory board, 
common sense dictates that the board should include members with professional legal or accounting experience and business experience. Advisory board members should also come from outside the company. An attorney or accountant retained as a professional by the company might be less willing to provide a critical assessment than an outside professional. While the outsider does not provide the firm with actual services, he or she can offer an independent second opinion that is not available when the accountant or attorney is both retained by the firm and serves on the advisory board.

\section{Directors' Liability}

Directors' liability is generally based on the director's duty of care and fiduciary duty. In the family corporation, two other theories of liability are also important: piercing the corporate veil and liability for personal actions. In this section, we discuss these four types of liability.

Duty of Care. Directors are required by statute to exercise due care. In the words of Section 8.30 of the Model Act (Revised Model. .., 1985) a director must act "with the care an ordinarily prudent person in a like position would exercise under similar circumstances." State corporation laws also list specific types of liability from which the exercise of ordinary care is no protection. For example, these laws hold directors personally responsible for distribution of an illegal dividend, losses resulting from activities beyond its lawful powers, and contracts made in states where the corporation has not obtained a certificate of authority to conduct business.

Two factors mitigate the duty of care. First, directors are entitled to rely on reports, opinions, financial data, and other information supplied by company employees, professionals (legal counsel, accountants), or board committees-provided that directors have no reason to be suspicious of this information.

Second, and perhaps more important, courts have adopted a handsoff philosophy known as the business judgment rule when reviewing directors' decisions. In the words of the Delaware Supreme Court, the business judgment rule "is a presumption that in making a business decision the directors of a corporation acted on an informed basis, in good faith, and in the honest belief that the action taken was in the best interests of the company" (Aronson v. Lewis, 1984). This means that the party who challenges a business decision faces a difficult burden of proof. As a result, absent fraud or self-dealing, directors are rarely found liable for errors, mistakes, or simple bad judgment (Block, Barton, and Radin, 1987).

In addition to these legal factors, there are practical considerations that protect directors of a family corporation from liability. While it has 
been asserted that a lawsuit filed by shareholders is the most serious risk that corporate executives face (Bishop, 1982), in many family corporations all shareholders serve on the board. In cases where these shareholder-board members unanimously agree on a particular course of action, there are no shareholders left who can later assert that the board failed to exercise due care. Similarly, although actions seeking recovery from directors charged with violating securities law may be the fastestgrowing area of personal liability (Bishop, 1982), most family corporations do not have or seek public financing. Thus, the exposure of their directors under securities law is reduced.

This is not to say, however, the a director may ignore the business affairs of the corporation without risk of personal liability. There is case authority for holding a director personally liable for losses suffered by the corporation when those losses have been caused by the director's failure to discharge the duty of care. For instance, in Francis v. United Jersey Bank (1981), the Supreme Court of New Jersey held a director personally liable for the losses occasioned by the fraudulent acts of others. The director knew nothing about the corporation's affairs and had not even read financial statements that allegedly disclosed on their face the misappropriation of trust funds.

Fiduciary Duty. Directors owe a fiduciary duty to the corporation. As a result, contracts between a director and the corporation should be fair to the corporation, and a director should never personally enter into a business transaction in which the corporation might be interested.

Directors also owe a fiduciary duty to shareholders. In one case, a son who was the majority shareholder in a lumber company operated the company after the death of his father. While in the process of negotiating a sale of the company to Boise Cascade, he purchased shares held by his sister and brother without disclosing the pending sale to them. A court later held him liable for damages on the grounds that "a director has a fiduciary responsibility to both the corporation and to shareholders" (Weatherby v. Weatherby Lumber Co., 1972).

Piercing the Corporate Veil. The corporation represents a veil designed to protect its owners from personal liability. In the words of attorney Gilbert (a partner in Gilbert and Sullivan) in Utopia, Ltd.:

Though a Rothschild you may be in your own capacity, As a company you've come to utter sorrow-

But the liquidators say, "Never mind, you needn't pay," So you start another company tomorrow.

However, in family businesses there is a risk that courts will pierce the corporate veil and hold family members who serve as directors, shareholders, or employees personally liable if they have failed to treat the 
corporation as a separate entity. This is especially true when the corporation has a paper or rubber-stamp board.

As a result, close attention should be paid to legal formalities. Courts are especially inclined to pierce the corporate veil when directors do not meet on a regular basis, annual reports are not filed with the state, the corporation is undercapitalized, corporate assets are commingled with personal assets, and corporate funds are used for personal purposes.

Personal Actions. Even when the corporate veil is preserved, individuals are liable for their own actions when named as defendants in a civil lawsuit. This is a special concern in family corporations, where family members are active on several fronts as directors, officers, and employees. If, for example, a family member serving in these roles causes an automobile accident while on company business, there is personal liability; the corporate veil provides no protection, although the corporation itself might also be liable.

Individuals also face potential criminal liability for their own actions. In recent years, for instance, local prosect ting attorneys have perceived a decline in federal safety inspections of businesses and as a result have become more aggressive in filing criminal charges. In one well-publicized case, a company president, plant manager, and foreman were sentenced to twenty years in prison after a worker died as a result of unsafe working conditions at their company's plant (Tasini, 1986).

\section{Liability Prevention}

It is possible to minimize director liability on both a structural and a personal level. On a structural level, the corporation should agree to indemnify directors for expenses resulting from litigation. However, the corporation's ability to indemnify is frequently limited by law (for example, in cases where the corporation itself is suing a director) and by the corporation's financial ability to pay. Consequently, an indemnification agreement should be complemented by liability insurance. In a family business where the board has been eliminated or where the power of a board has been diluted by a shareholder agreement, the shareholders are the ones who need to be protected by indemnity and insurance arrangements.

Liability insurance has been problematic in recent years because it has become very expensive or even unavailable. As a result, Delaware and several other states have enacted legislation allowing corporations to eliminate the personal liability of outside directors to the corporation or its shareholders for failing to exercise due care.

The use of a board of advisers has been recommended as an alternative to the board of directors as a way of preventing directors' liability. While courts have not yet determined the extent to which an advisory board 
member may be held liable, this recommendation is highly suspect for two reasons. First, if the advisory board does in fact perform the functions of the board of directors, then it is possible that the advisers will be held just as liable as they would if they were directors. In other words, courts will probably place more emphasis on the substance of the arrangement than on the name that it assumes.

Second, if the board is indeed only advisory, the members are in effect acting as consultants. Although they may avoid the liability imposed on directors by statute, they still face liability if they give bad advice. For example, one executive who lost his outside directors was advised not to stay in touch with them. His lawyers concluded that the former directors could be held liable merely for providing advice (Blumenthal, 1986). The risk of liability is compounded by the fact that the usual mechanisms designed to protect directors-such as the business judgment rule, indemnification, and charter provisions limiting personal liability-may be unavailable to advisory board members who are acting as consultants. And, even when advisory board members are not held liable, the cost of litigation can be substantial.

Beyond these structural approaches, directors should be able to avoid liability on a personal level by acting in accordance with the two broad rules of thumb implicit in the business judgment rule and in the concept of fiduciary duty: First, all decisions should be made on an informed basis, with documentation sufficient to withstand a challenge in court. Second, the interests of the corporation should always come before personal interests.

To these general guidelines should be added one piece of procedural advice: A director who concludes that the board is making an imprudent or illegal decision should dissent and make certain that the negative vote is recorded. Otherwise, silence will be construed as consent to the action, and this in turn can lead to liability.

\section{Conclusion}

More than twenty-five years ago, Lord Boothby described the duties of a director ("Soft Boards," 1962, p. 96) as follows: "No effort of any kind is called for ... You go to a meeting once a month in a car supplied by the company. You look both grave and sage, and on two occasions say 'I agree,' say 'I don't think so' once, and if all goes well, you get $\$ 1,440 \mathrm{a}$ year. If you have five of them, it is total heaven, like having a permanent hot bath."

Times have changed. Over the past two decades, increased concern over liability has led directors to become much more involved in company operations. While this trend is positive, it has come at a steep price in terms of personal liability. However, the price can be reduced or even 
avoided if certain measures are taken. The benefits of these measures over the long run go far beyond keeping the director out of court. An active, informed board composed of members who place company interests before self-interests is the key to developing a sound organization that will benefit succeeding generations.

\section{References}

Aronson v. Lewis, 437 A.2d 805, 812 (Del. 1984).

Bishop, J. W., Jr. The Law of Corporate Officers and Directors Indemnification and Insurance. Wilmette, Ill.: Callaghan, 1982.

Block, D. J., Barton, N. E., and Radin, S. A. The Business Judgment Rule: Fiduciary Duties of Corporate Directors and Officers. Englewood Cliffs, N.J.: PrenticeHall, 1987.

Blumenthal, K. "Board Members Confront Loss of Outside Help." Wall Street Journal, June 2, 1986, p. 19.

"D\&O Liability Seen as a Crisis in the Making." Journal of Accountancy, July 1987, pp. 32, 34.

Danco, L. A. Beyond Survival: A Business Owner's Guide for Success. Cleveland, Ohio: University Press, 1982.

Dyer, W. G., Jr. Cultural Change in Family Firms: Anticipating and Managing Business and Family Transitions. San Francisco: Jossey-Bass, 1986.

Francis v. United Jersey Bank, 432 A.2d 814, 826 (1981).

Revised Model Business Corporation Act. New York: Law \& Business, Inc./Harcourt Brace Jovanovich, 1985.

"Soft Boards." Time, October 5, 1962, p. 96.

Tasini, J. "The Clamor to Make Punishment Fit the Crime: Local Prosecutors Are Taking Up Business Cases Once Relegated to Civil Suits." Business Week, February 10, 1986, p. 73.

Weatherby v. Weatherby Lumber Company, 492 P.2d 43, 45 (1972).

Cindy A. Schipani and George J. Siedel are professors at the School of Business Administration, University of Michigan. 